\title{
The Role of Strategic Communication Management in Nation Brand Building
}

\author{
Abdullah Özkan, İstanbul University, Turkey
}

\begin{abstract}
To be reputable, esteemed and reliable, countries must build their own "nation values" in the $21^{\text {st }}$ century. Therefore, countries gain many advantageous in the political, social and cultural fields as well as being an attraction center. For countries, the strategic communication management paves the way for proper planning, creating effective messages and conveying these messages to the target audiences smoothly and determines a road map to gain success. This paper analyses the multi-dimensional relation between strategic communication management and nation brand, underlines the necessary steps for building nation brand and makes offers for the future.
\end{abstract}




\section{Introduction}

Countries, like brands and institutions, have faced with a fierce competition environment in the new century. Many important changes with the globalization process, particularly in the communication industry, force countries to give up traditional techniques. Now countries should understand the new paradigm, decode and continue with the new methods and techniques. In this process, the idea that countries enhance the "brand values" and build their own "nation brand" gains importance.

This has become a strategic priority in the competition environment of the $21^{\text {st }}$ century that countries position themselves correctly and convey their messages to the public opinion effectively and consequently have a reputable, esteemed and reliable nation value. "Communication" is the most important strategic tool for countries to build their own nation brand. There is a multi-dimensional relation between strategic communication management and building/developing and enhancing the nation brand. In the paper, this relation has been studied and on building nation brand, important contributions of effective communication strategies have been analyzed. Also, why and how Turkey will build its nation brand are emphasized and on which parameters Turkey's nation brand should be built is discussed.

\section{The Notion of Strategic Communication}

American strategic communication consultant Emil Goldman, describes the strategic communication as "a strategy influencing attitude and behavior" (Karagöz, 2015:45). Influencing attitude and behavior is among the most difficult tasks now as individuals become conscious and communication technologies become widespread. This will be impossible if you fail to communicate and be listened/ watched by the audiences. Having a smooth and effective communication should be the first step before focusing on use of this method strategically. Strategic communication is not a passive, source-based communication process conveying the most favorable message to the concerned audiences that aims to inform public opinion. Instead, strategic communication is an active communication process based on sharing determined messages with the public opinion in the frame of vision and goals, influencing and manipulating the perception of public opinion positively. In strategic communication, these are aimed that concerned public opinion understands the vision, strategic goals, intention, activity and discourse of country/institution properly. Also, some disciplines such as public relations, information management, the public diplomacy, the 
relation with media, perception and reputation management are employed integrally in the strategic communication practices (Güncan, 2010: 105).

Strategic communication is a notion that generally used for describing the planned communication campaign. It is possible that a state, army, government or small groups could manage a strategic communication which could be also managed by a business or NGO. This means strategic communication is used both for business purposes and other purposes. Strategic communication is used for primarily formal studies (sometimes informal studies are used), a trouble, concerned target audiences, measurable goals and aims (Çınarlı, 2009: 5).Strategic communication has multi-dimensional structure and distinctive characteristics. These characteristics are arrayed as follows (Onat, 2012: 78):

a) There is a determined super-ordinate goal, target and a victory to gain that independent from communication processes.

b) Communication tools are pre-planned with the messenger, message and message retriever.

c) Alternative plans are studied to reach goals

d) Required tactic, methods and studies should be conveyed to have successful results after following determined strategy. The tactic is used in the parts of the integrity of strategy. Strategy is not the tactic.

e) It is provided that the message is taken for the determined purpose. Perception, decoding and understanding the message should be controlled. Also, the required measures should be taken for the aim that messages could only be understood by the target audiences.

f) The messenger should be prepared to convey the message properly.

g) For communication, the most developed technology is used

h) It is aimed about the critical and crucial topics that the target person/people take(s) the message subconsciously and while practicing this message that person/people have a perception of their own willing.

i) The required measures are taken to prevent the use of message by unintended audiences. 
Strategic communication; embodies planning, developing tactics, correcting coding to provide effective perception of the message, conveying the message to the target audiences in the most smooth and effective way and using the most developed technology. These distinctive characteristics of the strategic communication make it valuable and effective besides proper using provides successful results.

\section{Why Is Strategic Communication Management Important?}

Strategic communication management determines creating the messages, conveying the style, structuring the short and core messages, functionalizing the messages, the tools and methods choosing clear key notions and words that are repeated constantly,. It also does the coordination of states' communication activity and policies of the state, vision and activities practices integrally and coherently (Ekşi, 2014: 111).

In the globalization process it has great importance to know how to use the power of strategic communication. Policy or trade will be affected by the strategic management of communication at last. To reach a superior position in the global competition, these have great importance to take the correct decision in the right time, using the information effectively and behave proactively. The reason why strategic communication management has such an importance is its guiding characteristic for determining "communication policies and "a road map". On the other hand, this decides the context of "message" for the target audiences as well as "what to say". Moreover, a vision emerges knowing "what, how, and why to say" rather than a simple communication effort. With the development of mass media instruments in the globalization process, there have been great changes in the context and style of messages conveyed to the masses. The mass media has become diversified, communication process has become complicated and so the target audiences have become more separated. Strategic communication process, has gained the role of "decoder" as it solves the more complicated mass media process. Proactive approach is required rather than reactive one. At this point, Strategic Communication Management aims to determine the weak points rather than searching solution after a problem emerges, to enhance and solve these at the beginning. It makes long term studies rather than one-day studies. This permanent and healthy approach paves the way for the success. Strategic Communication Management measures the effectiveness of messages conveyed to the target audiences and determines the perception level while it instantly changes the discourse if there is a misunderstanding or lack 
of effectiveness. Thus, Strategic Communication Management prevents misunderstanding of target audiences (Özkan, 2015).

Considering the business, to have a success in the globalization process, "vision" based on competition, "management approach"-open to change- and unique " business culture" are necessary. To "Build Value" a strong brand, and institution image are crucial. Brand and institution image pave the way for gaining competitive advantageous by "presenting value". Building a strong brand and institution image is only possible with displaying a difference in technology, customer satisfaction, social responsibility, quality notable presented good and service. To exhibit "a difference" a strong "institution image" is necessary. Countries also need the same differences. In the globalization process, countries also present their management approach transparently, create their own cultures about the basic topics such as democracy, human rights and freedom and make efforts to create their own images. The “perception” of countries' about us has great importance (Özkan, 2015).

\section{The Notion of the $21^{\text {st }}$ Century: "Nation Brand"}

The notion of nation brand becoming prominent in the $21^{\text {st }}$ century has made contributions to the competition between countries in the fields of economy, politic, society and culture. Countries building brand value will lose power in competition if they fail to build their own brand and exhibit difference while becoming an "attraction center". As Anholt underlines, world is a market area and each country must compete to share trade, policy and sociocultural events of the world. Have a brand in such a market is crucially important for countries (2008: 31).Countries fail to build a brand could not draw the foreign invest and tourists, increase the exports and living standards (Gilboa, 2008: 67).It is observed that the image and reputation of country manage the strategic communication process properly and take the support of foreign public opinion, have developed positively in the international environment (İnan, 2012:66). This positive message enhances the nation values of countries. Big brands and business always search new regions to produce goods more cheaply. On the other hand, underdeveloped and developing countries lean towards the foreign invest as new working opportunities will emerge and so employment will increase through the foreign investors. For big brands and producers the tax practices, transportation facilities and regulations of countries in which they make investment have great importance. Moreover, political and economic stability and smooth and free competition area are crucial for the 
foreign investors. These are among the obstacles that stop the foreign capital flow; unfair competition environment caused by changing practices according to people or terms, redtapes, unrecorded economy, unequal and inconsistent practices. However, while the foreign investors are choosing the country for making investment, they have been influenced by the image and perception of countries in the world scene either positively or negatively. On the other hand, tourism- as a $4^{\text {th }}$ great sector of the world- is an effective field to promote countries. It should be clearly said that only sea, sand and sun are not enough to draw satisfied number of tourists. Thus, countries should create a new branding strategy with different elements by using their present potential (Y1ldırım, 2014: 157).

In today's world, countries fiercely compete with each other for the direct foreign investment, brand export and tourism. Countries are recalled by their brands and if these brands are demanded and used by big masses so the image of these countries gains advantageous (Olins, 2007: 172; Anhold, 2014: 296).With the studies of nation brand, image of countries is reshaped, through this image a new identity perception is gained and reflected on overseas. This process requires a long term, determined and patient study (Melissen, 2007: 21).

\section{Relation between Nation Brand and Public Diplomacy}

Public diplomacy -that embodies activities performed by governments for the interest, threat or possible threat based considerations and for influencing other public opinions- aims not the governments of other countries but their non-governmental actors and public opinions. With the help of public diplomacy, countries enable to build a dialogue between foreign citizens and their citizens as well as institutions. These are among the goals of public diplomacy; informing and influencing foreign public opinions, increasing this influence, eliminating the troubles caused by misunderstandings and prejudice by shaping the cross-border communication environment (Doğan, 2012: 13).Public diplomacy which is out of the traditional diplomacy includes interactions with NGOs, cultural communication process and efforts to create public opinion in foreign countries (Morrow). In the perception of public diplomacy, governments and NGOs enable to transfer their opinions to foreign NGOs and public opinions (İnan, 2012, 64). Public diplomacy, also, underlines the communication process initiated to create sympathy of foreign public opinions for views, ideals and interest of countries. In fact, countries aim to influence the behavior of foreign governments by influencing behavior and attitude of foreign societies (Snitzer, 2008: 206). 
To reach a success from public diplomacy policies, the followed policies should be rational, convincing, legal and defendable. This will be impossible to defend or explain an unfair policy to foreign public opinions based on illegal methods and violating international law (Kalın, 2012: 151).The public diplomacy policies of countries, primarily, update the image, enhance the sincerity between people and correct the misunderstandings. Thus, it enables to know and understand each other through education, exchange programs, scientific cooperation and tourism while positive perceptions are increasing and people are interacting. As a result, permanent and long term relations are established (Leonard and Alakeson, 2000: 10). Countries have come into a new term with the end of bipolar cold war era and following, the establishment of multi-polar new international system, rapid developments in communication and informatics technology and more fierce competition. Now, there is no "relatively" safe world of cold war era. Contrary, there is a competitive world which is open for all developments, changing rapidly, having political, economic, social and cultural results and difficult to predict. In fact, for countries, existing and surviving in this world, taking place in the competition and keep the power are not so easy. These are not guarantees for the future and security in the new multi-polar international system to produce, sell and earn much or being a super and powerful country. The reason is that conditions are changing in any time. Thus, influencing the public opinion, that had no meaning in the old system but now becomes principal actor, has strategic importance (Özkan, 2014: 3).

Thus, nation "branding" has become a topic differs the countries from others in competition, communication and technological innovations and value produce. In the new international system in which strategic communication, perception, image, reputation and reliability gain importance, countries have faced to an obligatory to reshape, build and position in the eyes of public opinion like commercial brands (Erzen,2012,115). These are important in creating public opinion perception to inform properly and exactly, effective communication, open feedback channels and effective design of messages besides a branding road map under the guidance of strategic communication management should be followed to create reliable, strong, prestigious and reputable country image (Özkan, 2014: 3).The notions; public diplomacy and nation brand are complete each other. Public diplomacy points the general vision, establishes the ground for nation brand and prepares infrastructure to have successful 
results. Without this infrastructure, countries could not develop their brands and have permanent successful results.

\section{Conclusion}

The $21^{\text {st }}$ century there has been a fierce competition which makes the condition more difficult not only for individuals and institutions but also countries. Goods and services could only survive with building brand value and exhibit their distinctive characteristics and so they could be preferred. The same requirement is valid for countries. The condition of $21^{\text {st }}$ century makes countries build their brand value, displaying and enhancing their differences and create a positive image and perception.

There are two basic parameters enabling countries to build their own brands: The first is, "Public Diplomacy Vision". Countries having public diplomacy vision become aware of soft power elements that could convince public opinions and they could have conscious of using the present potential. The second is, "Strategic Communication Management". Strategic communication management lead countries to plan properly, develop clever tactics, create effective messages and convey these messages to the target audiences in the best possible way. Countries managing the communication strategically could express themselves to foreign countries/societies more easily and create desired perception. A healthy and effective communication bridge brings knowing, understanding, compromising, friendship and cooperation. This bridge, enhancing on the base of trust, develops with intimacy. Building a nation brand could not be managed only with some technical practices. This is dramatically important that countries should have international values such as democracy, state of law, human right and freedom. Also, countries should interiorize these values and desire to spread in foreign societies. A successful country could only be built on these international values which could be transferred to the foreign societies with strategic communication management. As a result, attention of foreign societies could be drawn. 


\section{References}

Anholt, S. (2008).Engagement Public Diplomacy in a Globalised World. London: CW Print Group

Anholt, S. (2014).“YerleşimYerlerininveÜlkelerinMarkalaşması”.MarkalarveMarkalaşma (Ed. Rita Clifton). İstanbul: İşBankasıKültür Publishing

Çınarlı, İ. (2009). StratejikilletişimYönetimi, İstanbul: Beta Printing Publishing Distribution

Doğan, E. (2012). “KamuDiplomasisininsunduğufırsatlarvekısıtlarüzerine”.KamuDiplomasisi (Ed: Abdullah Özkan-Tuğçe Ersoy Öztürk). İstanbul: Tasam Publishing

Ekşi, M. (2014).KamuDiplomasisive AK PartiDönemiTürkDışPolitikası. Ankara: SiyasalKitabevi.

Gilboa, E. (2008). "Searching for a Theory of Public Diplomacy".The Annals of The American Academy of Political and Social Science. Volume 616

Gürcan, M.

(2010).“StratejikİletişimModeliVeGüvenlikAlanınaUygulanabilirliği”.GüvenlikStratej ileriMagazine. Year:8. Nu:15. Ankara: Institutionfor Strategic Research

Kalın, İ. (2012). “TürkDışPolitikasıveKamuDiplomasisi”.KamuDiplomasisi (Ed: Abdullah Özkan-Tuğçe Ersoy Öztürk). İstanbul: Tasam Publishing

Karagöz, S. (2015).StratejikiletişimyönetimiOlarakkamuDiplomasisivemedya. Social Sciences at Istanbul University (Master Thesis)

Leonard, M., Alakeson, V. (2000).Going Public: Diplomacy for he Information Society. London: The Foreign Policy Center

İnan, E. (2012).“KamuDiplomasisiveHalklaİlişkilerEkseni”.KamuDiplomasisi (Ed: Abdullah Özkan-Tuğçe Ersoy Öztürk). İstanbul: Tasam Publishing

Melissen, J. (2007).“The New Public Diplomacy: Between Theory and Practice”, The New Public Diplomacy, Newyork: Palgrave Macmillan

Morrow. E. R. "What is Public Diplomasi?".Center of Public Diplomacy. (http://fletcher.tufts.edu/murrow/public-diplomacy.html, Accessed:28.04.2015)

Onat, H. (2012). "DinselïletişiminStratejikBoyutu”, StratejikiletişimveAlglYönetimi, (Ed. BaharSenemÇevikErsayd1, RifatSeravillhan). Ankara: Ankara UniversityPublishing

Olins, W. (2007)."Making a National Brand”.The New Public Diplomacy, Newyork: Palgrave Macmillan

Özkan, A. (2014). "Role of public diplomacy in establishing nation branding and public diplomacy possibilities of Turkey”.International Association of Social Science 
Research. ISSN: 2147-6284. Special Issue: International Relations

Özkan, A. (2015). "Stratejikl̇letişimYönetimiveTürkiye".

http://www.siyasaliletisim.org/ariv/yorum/384-stratejik-letiim-yoenetimi-ve-tuerkiye.html (Accessed: 29.04.2015)

Signitzer,B. (2008). "Public Relations and Public Diplomacy, Some Conceptual Explorations”. AnsgarZerfass, Betteke van Ruler, Krishnamurthy Sriramesh, (Eds.), Public Relations Research-European and Internationals Perspectives and Innovations, VS VerlagfürSozialwissenschaften

Yıldırım, G. (2014). UluslararasıHalklaİlişkilerPerspektifindenKamuDiplomasisi: TürkiyeKamuDiplomasisiKoordinatörlüğüÖrneğiÇerçevesindeKültürelDiplomasi. (Published Doctoral Thesis) Social Sciences at Istanbul University 